\title{
Halomonas gomseomensis sp. nov., Halomonas janggokensis sp. nov., Halomonas salaria sp. nov. and Halomonas denitrificans sp. nov., moderately halophilic bacteria isolated from saline water
}

\author{
Correspondence \\ Sung-Taik Lee \\ e_stlee@kaist.ac.kr
}

\author{
Kwang Kyu Kim, Long Jin, Hee Chan Yang and Sung-Taik Lee \\ Department of Biological Sciences, Korea Advanced Institute of Science and Technology, \\ 373-1 Guseong-dong, Yuseong-gu, Daejeon 305-701, Republic of Korea
}

The family Halomonadaceae of the class Gammaproteobacteria comprises five genera, Carnimonas, Chromohalobacter, Cobetia, Halomonas and Zymobacter, which accommodate halophilic/halotolerant and non-halophilic bacteria (Arahal et al., 2002a, b; Franzmann et al., 1988). Nearly one-third of the species within the family Halomonadaceae have undergone taxonomic changes (Arahal et al., 2001, 2002a; Dobson \& Franzmann, 1996; Mellado et al., 1995) and, recently, [Pseudomonas] beijerinckii has been reclassified as Chromohalobacter beijerinckii (Peçonek et al., 2006). Nevertheless, the taxonomic status of some taxa, e.g. Cobetia marina and Halomonas marisflavi, is still in doubt.

The members of genus Halomonas are moderately halophilic bacteria, and the genus contains 35 recognized species. The type species is Halomonas elongata. Recently, Halomonas almeriensis (Martínez-Checa et al., 2005), Halomonas campaniensis (Romano et al., 2005) and Halomonas taeanensis (Lee et al., 2005) have been described. During the screening of salt-loving bacteria that might be applied to the

The GenBank/EMBL/DDBJ accession numbers for the 16S rRNA gene sequences of $H$. gomseomensis $M 12^{\top}, H$. janggokensis $M 24^{\top}, H$. salaria $\mathrm{M}_{2} 7^{\top}$ and $H$. denitrificans $\mathrm{M}^{2} 9^{\top}$ are AM229314-AM229317, respectively.

Transmission electron micrographs of cells of strains $\mathrm{M}^{2} 2^{\top}, \mathrm{M} 24^{\top}$, $\mathrm{M} 27^{\top}$ and $M 29^{\top}$, detailed DNA-DNA hybridization results and results of API ZYM tests are available as supplementary material in IJSEM Online. bioremediation of saline environments, we isolated 34 Halomonas strains from saline samples of sea and solar salterns in Anmyeondo, ten strains of which were considered to belong to novel species in the genus Halomonas and were subjected to a polyphasic taxonomic investigation.

Strains $\mathrm{M} 12^{\mathrm{T}}$ and M59 were isolated from saline water of Gomseom solar saltern, strains $\mathrm{M} 24^{\mathrm{T}}$ and M58 were isolated from saline water of Janggok solar saltern and strains $\mathrm{M} 27^{\mathrm{T}}, \mathrm{M} 66, \mathrm{M} 67, \mathrm{M} 29^{\mathrm{T}}, \mathrm{M} 69$ and M70 were isolated from seawater in Anmyeondo. For most experiments, strains were cultured on marine agar or broth (Difco) containing $10 \%$ $\mathrm{NaCl}$ at $28^{\circ} \mathrm{C}$ for $48 \mathrm{~h}$. When strains were cultured on other complex media for phenotypic tests, the final $\mathrm{NaCl}$ concentration was adjusted to $10 \%$.

The Gram reaction was performed as described by Gerhardt et al. (1994). Cell morphology and motility was observed under a phase-contrast microscope (Nikon Optiphot; $\times 1000$ magnification) with cells grown for 1-7 days, and the presence of flagella was determined by transmission electron microscopy (JEM-10111; JEOL) after negative staining with $2 \%(\mathrm{w} / \mathrm{v})$ uranyl acetate. Oxidase activity was tested using $1 \%$ tetramethyl-p-phenylenediamine (Tarrand \& Groschel, 1982) and catalase activity was tested using $3 \%$ $\mathrm{H}_{2} \mathrm{O}_{2}$. Growth was investigated at temperatures ranging from 5 to $55^{\circ} \mathrm{C}$ at intervals of $5{ }^{\circ} \mathrm{C}$ and at $\mathrm{pH} 4-11$ at intervals of $1 \mathrm{pH}$ unit. Requirement for and tolerance of 
$\mathrm{NaCl}$ were determined in nutrient broth (Difco) supplemented with modified artificial seawater [containing $\left(1^{-1}\right)$ : $0-30(0,0.5,1,2,4,6,8,10,12,15,20,25$ and 30) $\% \mathrm{NaCl}$, $5.94 \mathrm{~g} \mathrm{MgSO}_{4} .7 \mathrm{H}_{2} \mathrm{O}, 4.53 \mathrm{~g} \mathrm{MgCl}_{2} .6 \mathrm{H}_{2} \mathrm{O}, 0.64 \mathrm{~g} \mathrm{KCl}$ and $1.3 \mathrm{~g} \mathrm{CaCl}_{2}$; Lee et al., 2005]. Hydrolysis of casein and starch was tested on casein agar and starch agar (Difco). The $\mathrm{H}_{2} \mathrm{~S}$ production test was performed on triple-sugar-iron agar (BBL). Carbon source utilization tests, acid production tests and additional physiological tests were performed using API 20NE, API 32GN, API 50CH and API ZYM galleries according to the instructions of the manufacturer (bioMérieux).

For the analysis of fatty acids, strains were cultured on tryptic soy agar (TSA; Difco) containing $10 \% \mathrm{NaCl}$ at $28{ }^{\circ} \mathrm{C}$ for 48 h. Halomonas anticariensis LMG $22089^{\mathrm{T}}$, Halomonas cupida DSM $4740^{\mathrm{T}}$, Halomonas desiderata DSM $9502^{\mathrm{T}}$, Halomonas hydrothermalis DSM $15725^{\mathrm{T}}$, Halomonas maura DSM $13445^{\mathrm{T}}$, Halomonas sulfidaeris DSM $15722^{\mathrm{T}}$, Halomonas ventosae DSM $15911^{\mathrm{T}}$, Halomonas venusta DSM $4743^{\mathrm{T}}$ and Chromohalobacter marismortui DSM $6770^{\mathrm{T}}$ were used as reference strains under the same conditions.

Fatty acid methyl esters were prepared and analysed as described previously (Klatte et al., 1994) using the standard Microbial Identification System (MIDI Inc.) for automated gas chromatographic analysis (Sasser, 1990; Kämpfer \& Kroppenstedt, 1996). Isoprenoid quinones were extracted and purified as described previously (Tindall, 1990); dried preparations were dissolved in $200 \mu \mathrm{l}$ 2-propanol and 1-10 $\mu$ l samples were separated by HPLC without further purification.

Extraction of genomic DNA, PCR-mediated amplification of the 16S rRNA genes and sequencing of purified PCR products were carried out according to Rainey et al. (1996). The 16S rRNA gene sequences were aligned with published sequences retrieved from EMBL using CLUSTAL X (Thompson et al., 1997) and edited using BioEdit (Hall, 1999). Phylogenetic trees were constructed on the basis of the neighbour-joining (Saitou \& Nei, 1987) and maximumparsimony (Fitch, 1971) methods; distances were estimated by the method of Jukes \& Cantor (1969) using MEGA version 2.1 (Kumar et al., 2001). The resultant tree topologies were evaluated by bootstrap analysis (Felsenstein, 1985) based on 1000 resampled datasets. DNA G+C contents were determined by HPLC after hydrolysis as described by Tamaoka \& Komagata (1984) and non-methylated $\lambda$ DNA (Sigma) was used as a standard. DNA-DNA hybridization to determine genomic relatedness was performed fluorometrically by the method of Ezaki et al. (1989) using DNA probes labelled with photobiotin (Sigma; A1935) and microdilution wells (Greiner Bio-one; 96-well microplate).

The novel Halomonas strains formed visible colonies (0.5-1.5 mm diameter) on marine agar with $10 \% \mathrm{NaCl}$ at $28{ }^{\circ} \mathrm{C}$ within $48 \mathrm{~h}$. Good growth occurred at temperatures ranging from 15 to $40^{\circ} \mathrm{C}$. The colonies were convex, translucent and circular with entire edges. Cells were aerobic, Gram-negative, catalase-positive, non-spore-forming rods and were motile with peritrichous or lateral/polar flagella. Transmission electron micrographs of cells of strains $\mathrm{M} 12^{\mathrm{T}}, \mathrm{M} 24^{\mathrm{T}}, \mathrm{M} 27^{\mathrm{T}}$ and $\mathrm{M} 29^{\mathrm{T}}$ are available as Supplementary Fig. S1 in IJSEM Online. Detailed physiological and biochemical characteristics are summarized in Table 1 and in the species descriptions.

The predominant quinone was ubiquinone Q-9; a small amount of Q-8 was also present. The fatty acid profiles of strains $\mathrm{M} 12^{\mathrm{T}}, \mathrm{M} 24^{\mathrm{T}}$ and $\mathrm{M} 29^{\mathrm{T}}$ were similar to those of related taxa; the fatty acids $\mathrm{C}_{18: 1} \omega 7 c, \mathrm{C}_{16: 0}$ and summed feature $4\left(\mathrm{C}_{16: 1} \omega 7 c / \mathrm{C}_{15: 0}\right.$ iso 2-OH) were predominant. Strain $M 27^{\mathrm{T}}$ showed a slightly different profile; $\mathrm{C}_{18: 1} \omega 7 c$, $\mathrm{C}_{16: 0}$ and $\mathrm{C}_{19: 0}$ cyclo $\omega 8 c$ were predominant. Detailed fatty acid compositions are shown in Table 2.

The almost-complete 16S rRNA gene sequences (approx. $1480 \mathrm{nt}$ ) of the ten strains were determined and compared with those of existing species within the family Halomonadaceae. Strains $\mathrm{M}^{\mathrm{T}}{ }^{\mathrm{T}}$ and M59, which shared $99.4 \%$ similarity, showed the highest similarity to strain $\mathrm{M} 24^{\mathrm{T}}, H$. hydrothermalis ATCC BAA- $800^{\mathrm{T}}$ and $H$. venusta DSM $4743^{\mathrm{T}}$ (97.4, 97.2 and 97.1\%, respectively). Strains M24 ${ }^{\mathrm{T}}$ and M58, which shared $99.8 \%$ similarity, showed the highest similarity to strain $\mathrm{M} 12^{\mathrm{T}}$ and $H$. sulfidaeris ATCC BAA$803^{\mathrm{T}}$ (97.4 and $97.3 \%$, respectively). Strains $\mathrm{M} 27^{\mathrm{T}}$, M66 and M67, which shared $100 \%$ similarity, showed the highest similarity to $H$. anticariensis LMG $22089^{\mathrm{T}}(94.5 \%)$. Strains M29 ${ }^{\mathrm{T}}$, M69 and M70, which shared $99.8-100 \%$ similarity, showed the highest similarity to $H$. ventosae CECT $5797^{\mathrm{T}}, H$. maura CECT $5298^{\mathrm{T}}$ and H. cupida DSM $4740^{\mathrm{T}}(97.7,97.4$ and $97.0 \%$, respectively). The ten strains formed four separate lineages in the genus Halomonas in the phylogenetic trees (Fig. 1).

DNA-DNA hybridization tests were performed among the novel Halomonas strains and the type strains of closely related Halomonas species to confirm the taxonomic status of the novel strains. According to the DNA-DNA hybridization levels, strains $\mathrm{M} 12^{\mathrm{T}}$ and M59, which shared $90 \%$ relatedness, showed $21-41 \%$ hybridization with strain $\mathrm{M} 24^{\mathrm{T}}, H$. hydrothermalis DSM $15725^{\mathrm{T}}$ and $H$. venusta DSM $4743^{\mathrm{T}}$. Strains $\mathrm{M} 24^{\mathrm{T}}$ and M58, which shared $93 \%$ relatedness, showed $31-37 \%$ hybridization with strain $\mathrm{M} 12^{\mathrm{T}}$ and $H$. sulfidaeris DSM $15722^{\mathrm{T}}$. Strains $\mathrm{M} 27^{\mathrm{T}}$, M66 and M67 shared 99-100\% hybridization with each other. Strains M29 ${ }^{\mathrm{T}}$, M69 and M70, which shared 99-100\% relatedness, showed 15-39\% hybridization with $H$. ventosae DSM $15911^{\mathrm{T}}$, H. maura DSM $13445^{\mathrm{T}}$ and H. cupida DSM $4740^{\mathrm{T}}$. Consequently, the DNA-DNA hybridization results (Supplementary Table S1 in IJSEM Online) supported the proposal of four novel Halomonas species.

Combined phenotypic and genotypic data support that the ten novel strains represent four novel species in the genus Halomonas, for which the names Halomonas gomseomensis sp. nov., Halomonas janggokensis sp. nov., Halomonas salaria sp. nov. and Halomonas denitrificans sp. nov. are proposed. 
Table 1. Differential phenotypic characteristics of the novel Halomonas species, closely related Halomonas species and Chromohalobacter marismortui

Species: 1, H. gomseomensis sp. nov.; 2, H. janggokensis sp. nov.; 3, H. salaria sp. nov.; 4, H. denitrificans sp. nov.; 5, H. anticariensis; 6, H. cupida; 7, H. desiderata; 8, H. hydrothermalis; 9, H. maura; 10, H. sulfidaeris; 11, H. ventosae; 12, H. venusta; 13, Chromohalobacter marismortui. +, Positive; -, negative; ND, not reported. Data were taken from Arahal et al. (2002b), Bouchotroch et al. (2001), Kaye et al. (2004), Martínez-Cánovas et al. (2004a, b) and this study.

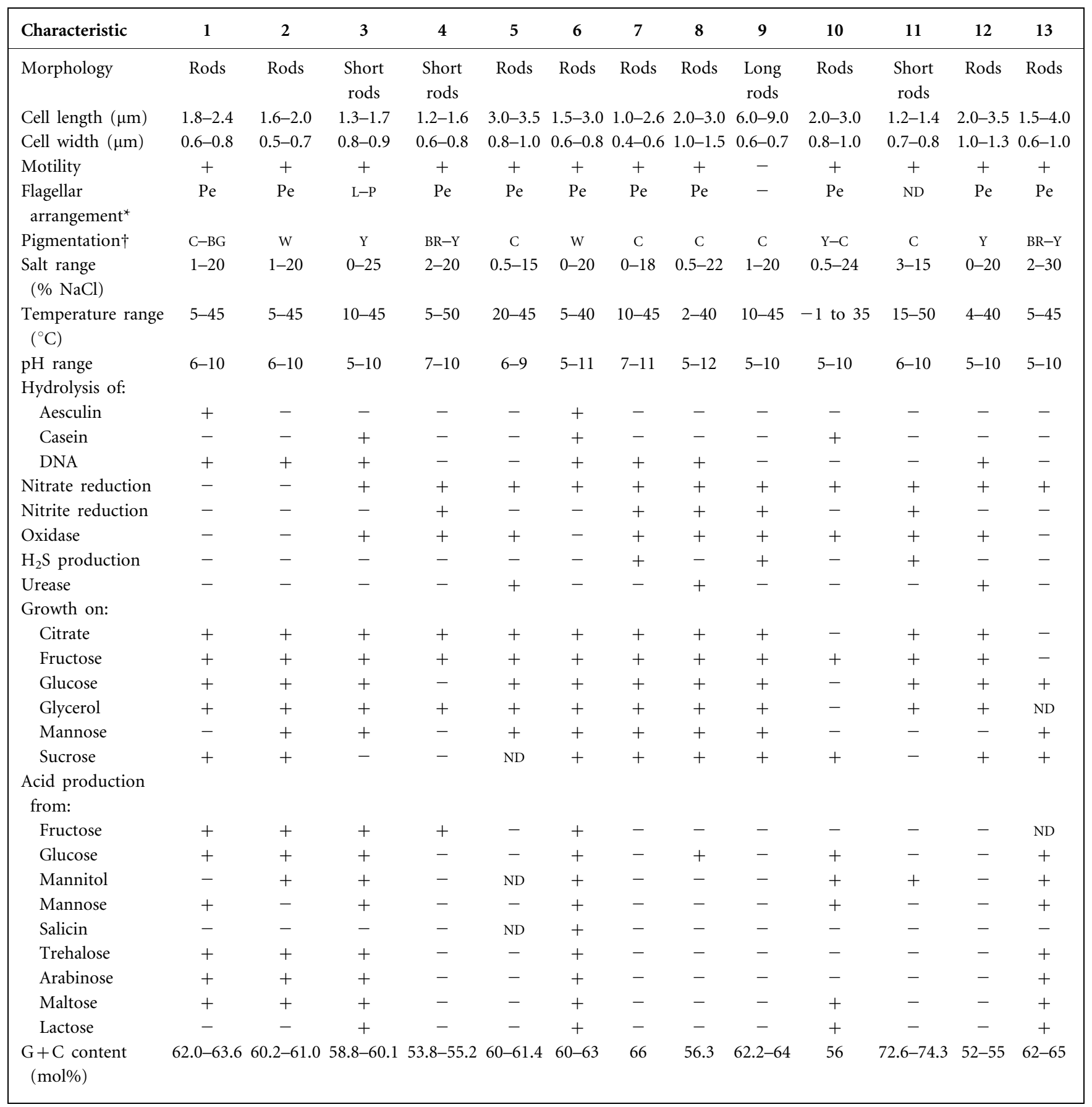

${ }^{\star} \mathrm{L}-\mathrm{P}$, Lateral/polar; Pe, peritrichous.

$\dagger B G$, Beige; BR, brown; C, cream; W, white; Y, yellow. 
Table 2. Cellular fatty acids of the type strains of novel Halomonas species and related taxa

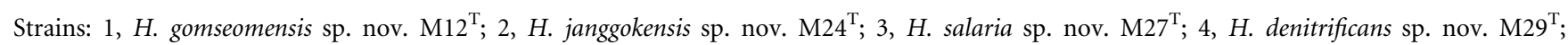
5, H. anticariensis LMG $22089^{\mathrm{T}}$; 6, H. cupida DSM $4740^{\mathrm{T}} ; 7$, H. desiderata DSM $9502^{\mathrm{T}} ; 8$, H. hydrothermalis DSM 15725 ; 9, H. maura DSM $13445^{\mathrm{T}}$; 10, H. sulfidaeris DSM $15722^{\mathrm{T}}$; 11, H. ventosae DSM $15911^{\mathrm{T}}$; 12, H. venusta DSM $4743^{\mathrm{T}}$; 13 , Chromohalobacter marismortui DSM $6770^{\mathrm{T}}$. Fatty acids are listed using standard abbreviations (number of carbon atoms: number of double bonds). Fatty acids that account for less than $1.0 \%$ of the total fatty acids in all strains studied are not shown. Therefore, the percentages do not add up to $100 \%$. tr, Trace $(<1.0 \%)$; ND, not detected.

\begin{tabular}{|c|c|c|c|c|c|c|c|c|c|c|c|c|c|}
\hline Fatty acid & 1 & 2 & 3 & 4 & 5 & 6 & 7 & 8 & 9 & 10 & 11 & 12 & 13 \\
\hline $\mathrm{C}_{10: 0}$ & 2.0 & 2.1 & 2.2 & 2.4 & 2.5 & 3.2 & 1.5 & 1.1 & 2.8 & 1.2 & 2.5 & 2.2 & 3.6 \\
\hline $\mathrm{C}_{12: 0}$ & $\operatorname{tr}$ & $\mathrm{ND}$ & 3.0 & ND & 3.7 & 4.1 & ND & $\operatorname{tr}$ & 3.3 & $\operatorname{tr}$ & ND & 1.2 & 4.3 \\
\hline $\mathrm{C}_{12: 0} 3-\mathrm{OH}$ & 10.0 & 8.3 & 8.3 & 7.4 & 5.5 & 7.5 & 3.7 & 6.1 & 6.5 & 8.1 & 6.9 & 6.6 & 11.2 \\
\hline $\mathrm{C}_{14: 0}$ & $\mathrm{ND}$ & ND & ND & ND & $\mathrm{ND}$ & $\mathrm{ND}$ & 2.6 & 3.2 & $\operatorname{tr}$ & ND & ND & 2.6 & $\mathrm{ND}$ \\
\hline Summed feature $4^{*}$ & 9.7 & 7.6 & 10.0 & 21.2 & 13.2 & 14.2 & 3.8 & 11.7 & 19.5 & 8.4 & 18.3 & 11.5 & 9.2 \\
\hline$C_{16: 0}$ & 16.5 & 12.4 & 20.4 & 21.1 & 25.6 & 21.5 & 15.9 & 14.8 & 20.5 & 8.7 & 20.3 & 14.0 & 16.7 \\
\hline $\mathrm{C}_{17: 0}$ cyclo & $\mathrm{ND}$ & $\operatorname{tr}$ & 2.9 & $\mathrm{ND}$ & $\operatorname{tr}$ & $\mathrm{ND}$ & $\mathrm{ND}$ & $\mathrm{ND}$ & $\mathrm{ND}$ & $\mathrm{ND}$ & $\mathrm{ND}$ & $\mathrm{ND}$ & 1.0 \\
\hline $\mathrm{C}_{18: 1} \omega 7 c$ & 57.4 & 61.8 & 33.6 & 47.2 & 47.3 & 48.6 & 70.5 & 62.4 & 46.6 & 67.6 & 51.0 & 61.9 & 47.3 \\
\hline $\mathrm{C}_{18: 0}$ & ND & $\operatorname{tr}$ & 1.3 & ND & $\operatorname{tr}$ & $\operatorname{tr}$ & $\operatorname{tr}$ & ND & $\operatorname{tr}$ & $\mathrm{ND}$ & ND & $\mathrm{ND}$ & $\operatorname{tr}$ \\
\hline $\mathrm{C}_{19: 0}$ cyclo $\omega 8 \mathrm{c}$ & 3.6 & 6.3 & 18.3 & $\operatorname{tr}$ & 1.1 & $\mathrm{ND}$ & 1.2 & $\mathrm{ND}$ & ND & 5.1 & 1.0 & $\mathrm{ND}$ & 6.1 \\
\hline
\end{tabular}

${ }^{*}$ Summed feature 4 contains $\mathrm{C}_{16: 1} \omega 7 c$ and/or $\mathrm{C}_{15: 0}$ iso 2-OH.

\section{Description of Halomonas gomseomensis sp. nov.}

Halomonas gomseomensis (gom.se.om.en'sis. N.L. fem. adj. gomseomensis referring to Gomseom in Anmyeondo, from where the first strains were isolated).

Cells are aerobic, Gram-negative, non-spore-forming rods $(0.6-0.8 \times 1.8-2.4 \mu \mathrm{m})$. Colonies are cream-beige, smooth, translucent and circular with entire edges and stick slightly to solid media. Cells are motile with peritrichous flagella. Oxidase-negative and catalase-positive. Growth occurs at 5-45 ${ }^{\circ} \mathrm{C}$ (optimum $25-30{ }^{\circ} \mathrm{C}$ ) and at $\mathrm{pH}$ 6-10 (optimum $\mathrm{pH} 7-8)$. Growth occurs at salinities of $1-20 \% \mathrm{NaCl}$ (optimum $8-12 \% \mathrm{NaCl}$ ). Indole and $\mathrm{H}_{2} \mathrm{~S}$ are not produced. Voges-Proskauer test is negative. Nitrate and nitrite are not reduced. Aesculin and DNA are hydrolysed, but casein, gelatin, starch, Tween 80 and urea are not. Acid is produced from glycerol, D-arabinose, L-arabinose, D-xylose, galactose, glucose, fructose, mannose, inositol, arbutin, aesculin, maltose, sucrose, trehalose, D-turanose, D-fucose and L-fucose, but not from erythritol, ribose, $\mathrm{L}$-xylose, adonitol, methyl $\beta$ D-xylose, sorbose, rhamnose, dulcitol, mannitol, sorbitol, methyl $\alpha$-D-mannoside, methyl $\alpha$-D-glucoside, $N$-acetylglucosamine, amygdalin, salicin, cellobiose, lactose, melibiose, inulin, melezitose, raffinose, starch, glycogen, xylitol, gentiobiose, D-lyxose, D-tagatose, D-arabitol, L-arabitol, gluconate, 2-ketogluconate and 5-ketogluconate. The following compounds are utilized as sole carbon sources: D-glucose, $\mathrm{N}$-acetylglucosamine, salicin, inositol, L-fucose, sucrose, maltose, L-arabinose, gluconate, propionate, malate, malonate, valerate, acetate, citrate, DL-lactate, histidine, L-alanine, 2-ketogluconate, 3-hydroxybutyrate, 4-hydroxybenzoate and L-proline. The following carbon sources are not utilized: mannitol, rhamnose, D-ribose, D-melibiose, mannose, D-sorbitol, itaconate, suberate, adipate, caprate, phenylacetate, 5-ketogluconate, glycogen, 3-hydroxybenzoate and L-serine. Results from API ZYM tests are available in Supplementary Table S2 in IJSEM Online. The predominant quinone is ubiquinone Q-9; a small amount of Q-8 is also present. The fatty acids $\mathrm{C}_{18: 1} \omega 7 c, \mathrm{C}_{16: 0}$ and $\mathrm{C}_{16: 1} \omega 7 c / \mathrm{C}_{15: 0}$ iso $2-\mathrm{OH}$ are predominant. The $\mathrm{G}+\mathrm{C}$ content of the DNA is $62.0-63.6 \mathrm{~mol} \%(62.0 \mathrm{~mol} \%$ for the type strain).

The type strain is $\mathrm{M} 12^{\mathrm{T}}\left(=\mathrm{KCTC} 12662^{\mathrm{T}}=\operatorname{DSM} 18042^{\mathrm{T}}\right.$ ), isolated from saline water of Gomseom solar saltern in Anmyeondo, Korea.

\section{Description of Halomonas janggokensis sp. nov.}

Halomonas janggokensis (jang.gok.en'sis. N.L. fem. adj. janggokensis referring to Janggok in Anmyeondo, from where the first strains were isolated).

Cells are aerobic, Gram-negative, non-spore-forming rods $(0.5-0.7 \times 1.6-2.0 \mu \mathrm{m})$. Colonies are white, smooth, translucent and circular with entire edges. Cells are motile with peritrichous flagella. Oxidase-negative and catalase-positive. Growth occurs at 5-45 ${ }^{\circ} \mathrm{C}$ (optimum $25-30{ }^{\circ} \mathrm{C}$ ) and at pH 6-10 (optimum pH 7-8). Growth occurs at salinities of $1-20 \% \mathrm{NaCl}$ (optimum $10-15 \% \mathrm{NaCl}$ ). Indole and $\mathrm{H}_{2} \mathrm{~S}$ are not produced. Voges-Proskauer test is negative. Nitrate and nitrite are not reduced. DNA is hydrolysed, but aesculin, casein, gelatin, starch, Tween 80 and urea are not. Acid is produced from glycerol, L-arabinose, adonitol, galactose, glucose, fructose, mannitol, sorbitol, maltose, sucrose, trehalose, xylitol, D-turanose, D-fucose, D-arabitol and 


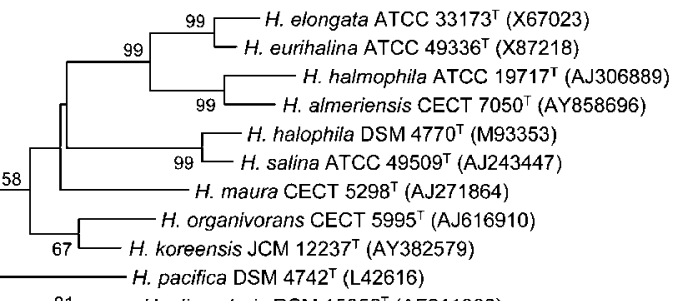

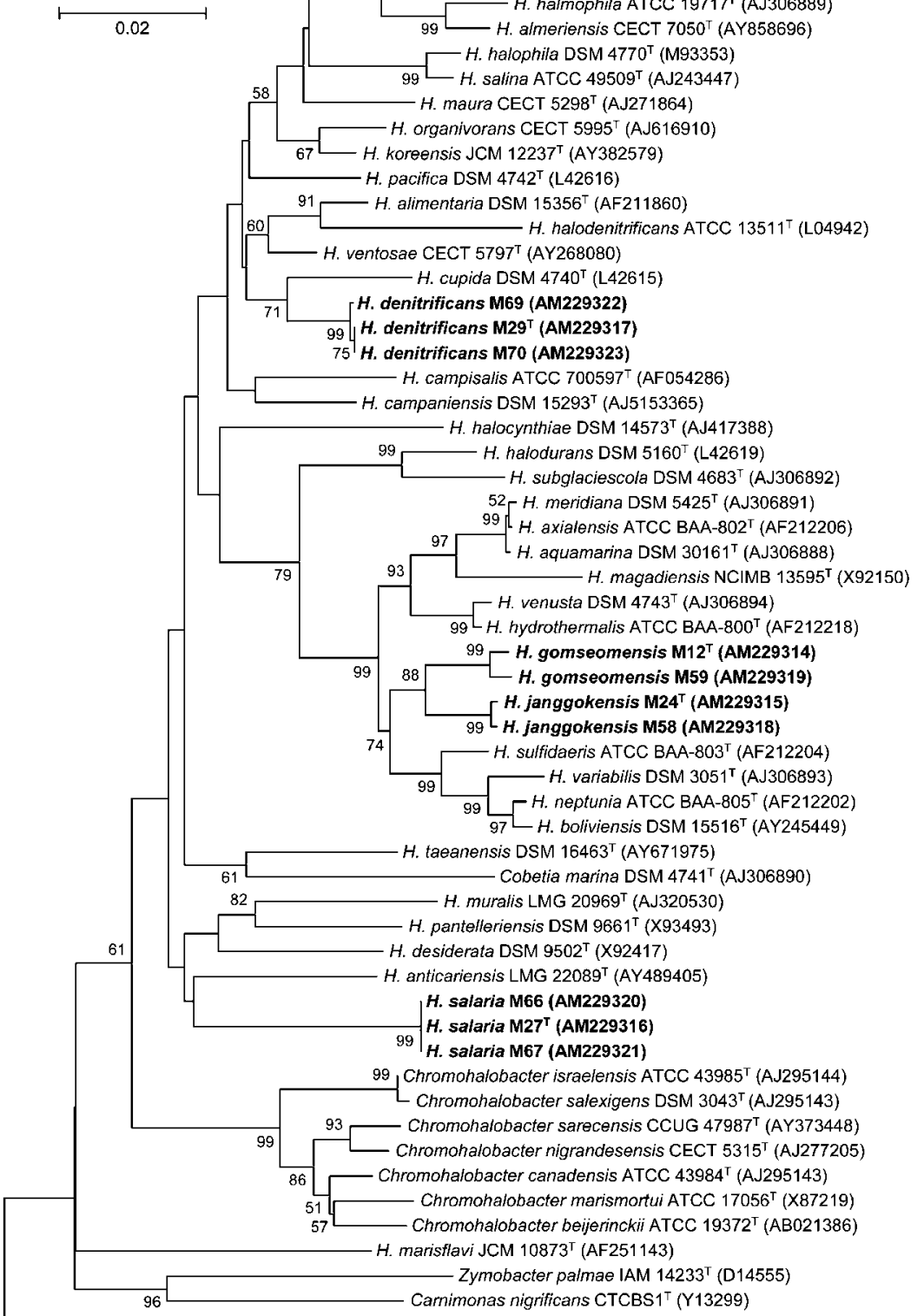

(b)

H. elongata ATCC $33173^{\top}(X 67023)$

H. halmophila ATCC $19717^{\top}$ (AJ306889)

H. almeriensis CECT 7050' (AY858696)

H. maura CECT 5298 (AJ271864)

${ }^{90}{ }^{H}$. alimentaria DSM $15356^{\top}$ (AF211860)

TCC ${ }^{\top}{ }^{\top}$ (L04942) H. campisalis ATCC 700597' (AF054286) $15293^{\top}(\mathrm{AJ} 5153365)$

H. ventosae CECT $5797^{\top}$ (AY268080)

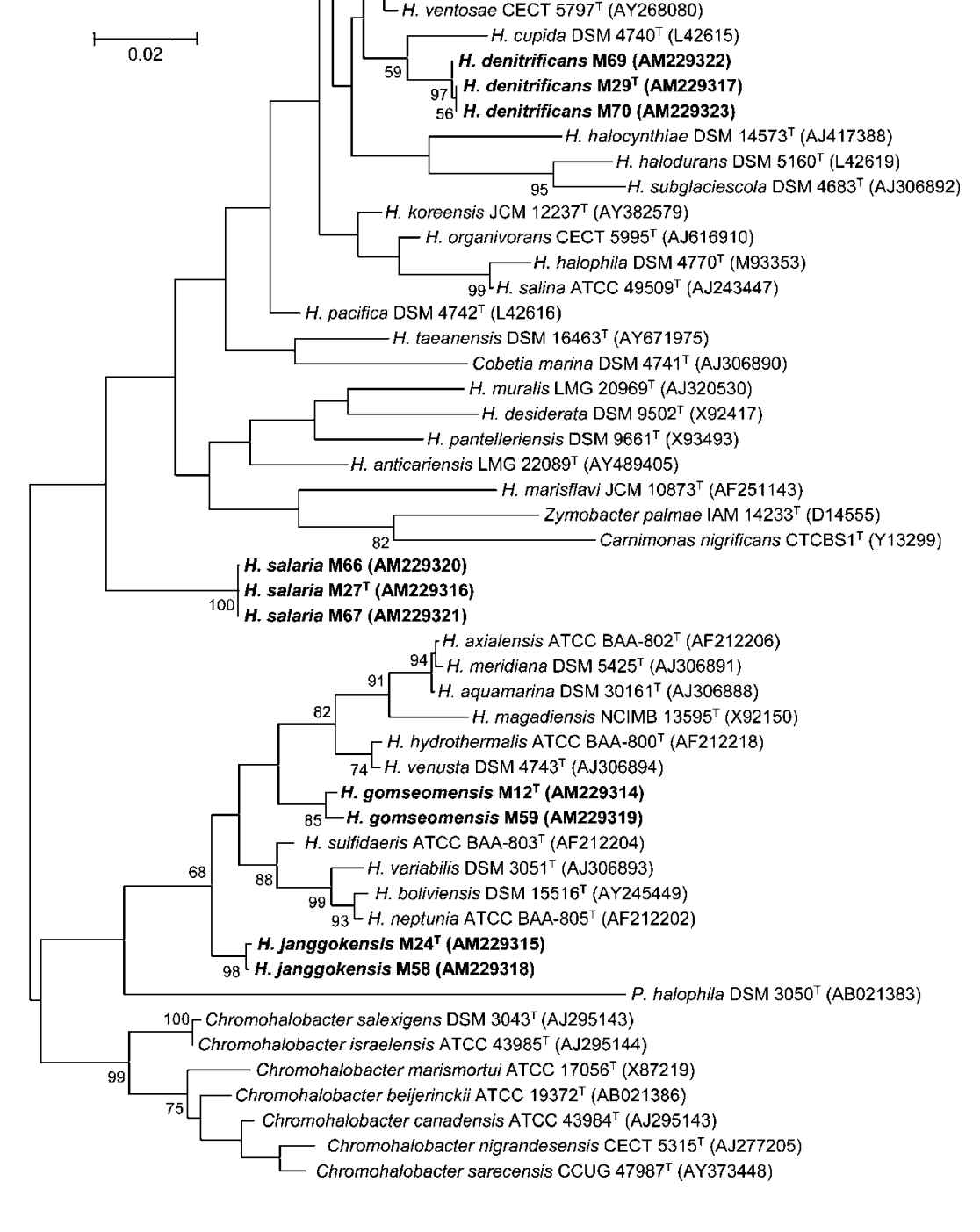

Fig. 1. Phylogenetic trees based on $16 \mathrm{~S}$ rRNA gene sequences using the neighbour-joining (Saitou \& Nei, 1987) (a) and maximum-parsimony (Fitch, 1971) (b) methods, showing the positions of the novel Halomonas strains among species of genera within the family Halomonadaceae. Numbers at branching points refer to bootstrap values (1000 resamplings; only values above $50 \%$ are shown). Bars, 2 substitutions per 100 nucleotide positions. 
L-arabitol, but not from erythritol, D-arabinose, ribose, Dxylose, L-xylose, methyl $\beta$-D-xylose, mannose, sorbose, rhamnose, dulcitol, inositol, methyl $\alpha$-D-mannoside, methyl $\alpha$-D-glucoside, $N$-acetylglucosamine, amygdalin, arbutin, aesculin, salicin, cellobiose, lactose, melibiose, inulin, melezitose, raffinose, starch, glycogen, gentiobiose, D-lyxose, D-tagatose, L-fucose, gluconate, 2-ketogluconate and 5-ketogluconate. The following compounds are utilized as sole carbon sources: mannitol, D-glucose, inositol, sucrose, maltose, D-sorbitol, L-arabinose, gluconate, propionate, malate, malonate, valerate, acetate, adipate, citrate, DL-lactate, L-alanine, 2-ketogluconate, 3-hydroxybutyrate and L-proline. The following carbon sources are not utilized: rhamnose, $\mathrm{N}$-acetylglucosamine, salicin, D-ribose, D-melibiose, L-fucose, mannose, itaconate, suberate, caprate, histidine, phenylacetate, 5-ketogluconate, glycogen, 4hydroxybenzoate, 3-hydroxybenzoate and L-serine. Results from API ZYM tests are available as Supplementary Table S2. The predominant quinone is ubiquinone Q-9; a small amount of Q-8 is also present. The fatty acids $\mathrm{C}_{18: 1} \omega 7 \mathrm{c}$, $\mathrm{C}_{16: 0}$ and $\mathrm{C}_{16: 1} \omega 7 c / \mathrm{C}_{15: 0}$ iso $2-\mathrm{OH}$ are predominant. The $\mathrm{G}+\mathrm{C}$ content of the DNA is $60.2-61.0 \mathrm{~mol} \%$ (61.0 $\mathrm{mol} \%$ for the type strain).

The type strain is $\mathrm{M} 24^{\mathrm{T}}\left(=\right.$ KCTC $\left.12663^{\mathrm{T}}=\mathrm{DSM} 18043^{\mathrm{T}}\right)$, isolated from saline water of Janggok solar saltern in Anmyeondo, Korea.

\section{Description of Halomonas salaria sp. nov.}

Halomonas salaria (sa.la'ri.a. L. fem. adj. salaria of or belonging to salt).

Cells are aerobic, Gram-negative, non-spore-forming rods $(0.8-0.9 \times 1.3-1.7 \mu \mathrm{m})$. Colonies are yellow, smooth, translucent and circular with entire edges. Cells are motile with lateral/polar flagella. Oxidase-positive and catalase-positive. Growth occurs at $10-45^{\circ} \mathrm{C}$ (optimum $25-30{ }^{\circ} \mathrm{C}$ ) and at pH 5-10 (optimum pH 7-8). Growth occurs at salinities of $0-25 \% \mathrm{NaCl}$ (optimum 10-20\% $\mathrm{NaCl}$ ). Indole and $\mathrm{H}_{2} \mathrm{~S}$ are not produced. Voges-Proskauer test is negative. Nitrate is reduced, but nitrite is not reduced. Casein and DNA are hydrolysed, but aesculin, gelatin, starch, Tween 80 and urea are not. Acid is produced from glycerol, erythritol, Larabinose, ribose, D-xylose, galactose, glucose, fructose, mannose, rhamnose, mannitol, cellobiose, maltose, lactose, melibiose, trehalose, D-lyxose, D-fucose and D-arabitol, but not from $\mathrm{D}$-arabinose, L-xylose, adonitol, methyl $\beta$-Dxylose, sorbose, dulcitol, inositol, sorbitol, methyl $\alpha$-Dmannoside, methyl $\alpha$-D-glucoside, $N$-acetylglucosamine, amygdalin, arbutin, aesculin, salicin, sucrose, inulin, melezitose, raffinose, starch, glycogen, xylitol, gentiobiose, D-turanose, D-tagatose, L-fucose, L-arabitol, gluconate, 2-ketogluconate and 5-ketogluconate. The following compounds are utilized as sole carbon sources: mannitol, Dglucose, D-ribose, L-fucose, maltose, mannose, L-arabinose, itaconate, gluconate, propionate, malate, valerate, acetate, adipate, citrate, DL-lactate, 2-ketogluconate, 5-ketogluconate, L-proline and L-serine. The following carbon sources are not utilized: rhamnose, $\mathrm{N}$-acetylglucosamine, salicin, Dmelibiose, inositol, sucrose, D-sorbitol, suberate, caprate, malonate, phenylacetate, histidine, L-alanine, 3-hydroxybutyrate, glycogen, 4-hydroxybenzoate and 3-hydroxybenzoate. Results from API ZYM tests are available as Supplementary Table S2. The predominant quinone is ubiquinone Q-9; a small amount of Q-8 is also present. The fatty acids $\mathrm{C}_{18: 1} \omega 7 c, \mathrm{C}_{16: 0}$ and $\mathrm{C}_{19: 0}$ cyclo $\omega 8 c$ are predominant. The $\mathrm{G}+\mathrm{C}$ content of the DNA is $58.8-60.1 \mathrm{~mol} \%$ (58.8 mol\% for the type strain).

The type strain is $\mathrm{M} 27^{\mathrm{T}}\left(=\right.$ KCTC $12664^{\mathrm{T}}=$ DSM $\left.18044^{\mathrm{T}}\right)$, isolated from seawater in Anmyeondo, Korea.

\section{Description of Halomonas denitrificans sp. nov.}

Halomonas denitrificans (de.ni.tri'fi.cans. N.L. v. denitrifico to denitrify; N.L. part. adj. denitrificans denitrifying).

Cells are aerobic, Gram-negative, non-spore-forming rods $(0.6-0.8 \times 1.2-1.6 \mu \mathrm{m})$. Colonies are brown-yellow, smooth, translucent and circular with entire edges. Cells are motile with peritrichous flagella. Oxidase-positive and catalase-positive. Growth occurs at $5-50{ }^{\circ} \mathrm{C}$ (optimum $25-35^{\circ} \mathrm{C}$ ) and at $\mathrm{pH} 7-10$ (optimum $\mathrm{pH}$ 8-9). Growth occurs at salinities of 2-20\% $\mathrm{NaCl}$ (optimum 8-10\% $\mathrm{NaCl}$ ). Indole and $\mathrm{H}_{2} \mathrm{~S}$ are not produced. Voges-Proskauer test is negative. Nitrate and nitrite are reduced. Aesculin, casein, DNA, gelatin, starch, Tween 80 and urea are not hydrolysed. Acid is produced from fructose, but not from glycerol, erythritol, D-arabinose, L-arabinose, ribose, Dxylose, L-xylose, adonitol, methyl $\beta$-D-xylose, galactose, glucose, mannose, sorbose, rhamnose, dulcitol, inositol, mannitol, sorbitol, methyl $\alpha$-D-mannoside, methyl $\alpha$-Dglucoside, $\mathrm{N}$-acetylglucosamine, amygdalin, arbutin, aesculin, salicin, cellobiose, maltose, lactose, melibiose, sucrose, trehalose, inulin, melezitose, raffinose, starch, glycogen, xylitol, gentiobiose, D-turanose, D-lyxose, D-tagatose, Dfucose, L-fucose, D-arabitol, L-arabitol, gluconate, 2-ketogluconate and 5-ketogluconate. The following compounds are utilized as sole carbon sources: propionate, malate, valerate, malonate, acetate, citrate, DL-lactate, L-alanine, 3hydroxybutyrate, L-proline and L-serine. The following carbon sources are not utilized: mannitol, D-glucose, rhamnose, $\mathrm{N}$-acetylglucosamine, salicin, D-ribose, D-melibiose, inositol, L-fucose, sucrose, D-sorbitol, maltose, mannose, L-arabinose, itaconate, suberate, adipate, caprate, gluconate, phenylacetate, histidine, 2-ketogluconate, 5ketogluconate, glycogen, 4-hydroxybenzoate and 3-hydroxybenzoate. Results from API ZYM tests are available as Supplementary Table S2. The predominant quinone is ubiquinone Q-9; a small amount of Q-8 is also present. The fatty acids $\mathrm{C}_{18: 1} \omega 7 c, \mathrm{C}_{16: 0}$ and $\mathrm{C}_{16: 1} \omega 7 c / \mathrm{C}_{15: 0}$ iso 2$\mathrm{OH}$ are predominant. The $\mathrm{G}+\mathrm{C}$ content of the DNA is $53.8-55.2 \mathrm{~mol} \%$ (53.8 $\mathrm{mol} \%$ for the type strain).

The type strain is $\mathrm{M} 29^{\mathrm{T}}\left(=\right.$ KCTC $\left.12665^{\mathrm{T}}=\mathrm{DSM} 18045^{\mathrm{T}}\right)$, isolated from seawater in Anmyeondo, Korea. 


\section{Acknowledgements}

This work was supported by Eco-Technopia-21, Ministry of Environment, Republic of Korea.

\section{References}

Arahal, D. R., Garcia, M. T., Ludwig, W., Schleifer, K. H. \& Ventosa, A. (2001). Transfer of Halomonas canadensis and Halomonas israelensis to the genus Chromohalobacter as Chromohalobacter canadensis comb. nov. and Chromohalobacter israelensis comb. nov. Int J Syst Evol Microbiol 51, 1443-1448.

Arahal, D. R., Castillo, A. M., Ludwig, W., Schleifer, K. H. \& Ventosa, A. (2002a). Proposal of Cobetia marina gen. nov., comb. nov., within the family Halomonadaceae, to include the species Halomonas marina. Syst Appl Microbiol 25, 207-211.

Arahal, D. R., Ludwig, W., Schleifer, K. H. \& Ventosa, A. (2002b). Phylogeny of the family Halomonadaceae based on $23 \mathrm{~S}$ and $16 \mathrm{~S}$ rDNA sequence analyses. Int J Syst Evol Microbiol 52, 241-249.

Bouchotroch, S., Quesada, E., del Moral, A., Llamas, I. \& Béjar, V. (2001). Halomonas maura sp. nov., a novel moderately halophilic, exopolysaccharide-producing bacterium. Int J Syst Evol Microbiol 51, $1625-1632$.

Dobson, S. J. \& Franzmann, P. D. (1996). Unification of the genera Deleya (Baumann et al. 1983), Halomonas (Vreeland et al. 1980), and Halovibrio (Fendrich 1988) and the species Paracoccus halodenitrificans (Robinson and Gibbons 1952) into a single genus, Halomonas, and placement of the genus Zymobacter in the family Halomonadaceae. Int J Syst Bacteriol 46, 550-558.

Ezaki, T., Hashimoto, Y. \& Yabuuchi, E. (1989). Fluorometric deoxyribonucleic acid-deoxyribonucleic acid hybridization in microdilution wells as an alternative to membrane filter hybridization in which radioisotopes are used to determine genetic relatedness among bacterial strains. Int J Syst Bacteriol 39, 224-229.

Felsenstein, J. (1985). Confidence limits on phylogenies: an approach using the bootstrap. Evolution 39, 783-791.

Fitch, W. M. (1971). Toward defining the course of evolution: minimum change for a specific tree topology. Syst Zool 20, 406-416.

Franzmann, P. D., Wehmeyer, U. \& Stackebrandt, E. (1988). Halomonadaceae fam. nov., a new family of the class Proteobacteria to accommodate the genera Halomonas and Deleya. Syst Appl Microbiol 11, 16-19.

Gerhardt, P., Murray, R. G. E., Wood, W. A. \& Krieg, N. R. (editors) (1994). Methods for General and Molecular Bacteriology. Washington, DC: American Society for Microbiology.

Hall, T. A. (1999). BIOEDIT: a user-friendly biological sequence alignment editor and analysis program for Windows 95/98/NT. Nucleic Acids Symp Ser 41, 95-98.

Jukes, T. H. \& Cantor, C. R. (1969). Evolution of protein molecules. In Mammalian Protein Metabolism, vol. 3, pp. 21-132. Edited by H. N. Munro. New York: Academic Press.

Kaye, J. Z., Márquez, M. C., Ventosa, A. \& Baross, J. A. (2004). Halomonas neptunia sp. nov., Halomonas sulfidaeris sp. nov., Halomonas axialensis sp. nov. and Halomonas hydrothermalis sp. nov.: halophilic bacteria isolated from deep-sea hydrothermal-vent environments. Int J Syst Evol Microbiol 54, 499-511.

Kämpfer, P. \& Kroppenstedt, R. M. (1996). Numerical analysis of fatty acid patterns of coryneform bacteria and related taxa. Can J Microbiol 42, 989-1005.

Klatte, S., Rainey, F. A. \& Kroppenstedt, R. M. (1994). Transfer of Rhodococcus aichiensis Tsukamura 1982 and Nocardia amarae
Lechevalier and Lechevalier 1974 to the genus Gordona as Gordona aichiensis comb. nov. and Gordona amarae comb. nov. Int J Syst Bacteriol 44, 769-773.

Kumar, S., Tamura, K., Jakobsen, I.-B. \& Nei, M. (2001). MEGA2: molecular evolutionary genetics analysis software. Bioinformatics $\mathbf{1 7}$, 1244-1245.

Lee, J.-C., Jeon, C. O., Lim, J.-M., Lee, S.-M., Lee, J.-M., Song, S.-M., Park, D.-J., Li, W.-J. \& Kim, C.-J. (2005). Halomonas taeanensis sp. nov., a novel moderately halophilic bacterium isolated from a solar saltern in Korea. Int J Syst Evol Microbiol 55, 2027-2032.

Martínez-Cánovas, M. J., Quesada, E., Llamas, I. \& Béjar, V. (2004a). Halomonas ventosae sp. nov., a moderately halophilic, denitrifying, exopolysaccharide-producing bacterium. Int J Syst Evol Microbiol 54, 733-737.

Martínez-Cánovas, M. J., Béjar, V., Martínez-Checa, F. \& Quesada, E. (2004b). Halomonas anticariensis sp. nov., from Fuente de Piedra, a saline-wetland wildfowl reserve in Málaga, southern Spain. Int J Syst Evol Microbiol 54, 1329-1332.

Martínez-Checa, F., Béjar, V., Martínez-Cánovas, M. J., Llamas, I. \& Quesada, E. (2005). Halomonas almeriensis sp. nov., a moderately halophilic, exopolysaccharide-producing bacterium from Cabo de Gata, Almería, south-east Spain. Int J Syst Evol Microbiol 55, 2007-2011.

Mellado, E., Moore, E. R. B., Nieto, J. J. \& Ventosa, A. (1995). Phylogenetic inferences and taxonomic consequences of $16 \mathrm{~S}$ ribosomal DNA sequence comparison of Chromohalobacter marismortui, Volcaniella eurihalina, and Deleya salina and reclassification of $V$. eurihalina as Halomonas eurihalina comb. nov. Int $J$ Syst Bacteriol 45, 712-716.

Peçonek, J., Gruber, C., Gallego, V., Ventosa, A., Busse, H.-J., Kämpfer, P., Radax, C. \& Stan-Lotter, H. (2006). Reclassification of Pseudomonas beijerinckii Hof 1935 as Chromohalobacter beijerinckii comb. nov., and emended description of the species. Int J Syst Evol Microbiol 56, 1953-1957.

Rainey, F. A., Ward-Rainey, N., Kroppenstedt, R. M. \& Stackebrandt, E. (1996). The genus Nocardiopsis represents a phylogenetically coherent taxon and a district actinomycete lineage; proposal of Nocardiopsaceae fam. nov. Int J Syst Bacteriol 46, 1088-1092.

Romano, I., Giordano, A., Lama, L., Nicolaus, B. \& Gambacorta, A. (2005). Halomonas campaniensis sp. nov., a haloalkaliphilic bacterium isolated from a mineral pool of Campania Region, Italy. Syst Appl Microbiol 28, 610-618.

Saitou, N. \& Nei, M. (1987). The neighbor-joining method; a new method for reconstructing phylogenetic trees. Mol Biol Evol 4, $406-425$.

Sasser, M. (1990). Identification of bacteria by gas chromatography of cellular fatty acids. Technical Note 101. Newark, DE: MIDI Inc.

Tamaoka, J. \& Komagata, K. (1984). Determination of DNA base composition by reverse-phased high-performance liquid chromatography. FEMS Microbiol Lett 25, 125-128.

Tarrand, J. J. \& Groschel, D. H. M. (1982). Rapid, modified oxidase test for oxidase-variable bacterial isolates. J Clin Microbiol 16, 772-774.

Thompson, J. D., Gibson, T. J., Plewniak, F., Jeanmougin, F. \& Higgins, D. G. (1997). The CLUSTAL X windows interface: flexible strategies for multiple sequence alignment aided by quality analysis tools. Nucleic Acids Res 25, 4876-4882.

Tindall, B. J. (1990). A comparative study of the lipid composition of Halobacterium saccarovorum from various sources. Syst Appl Microbiol 13, 128-130. 